
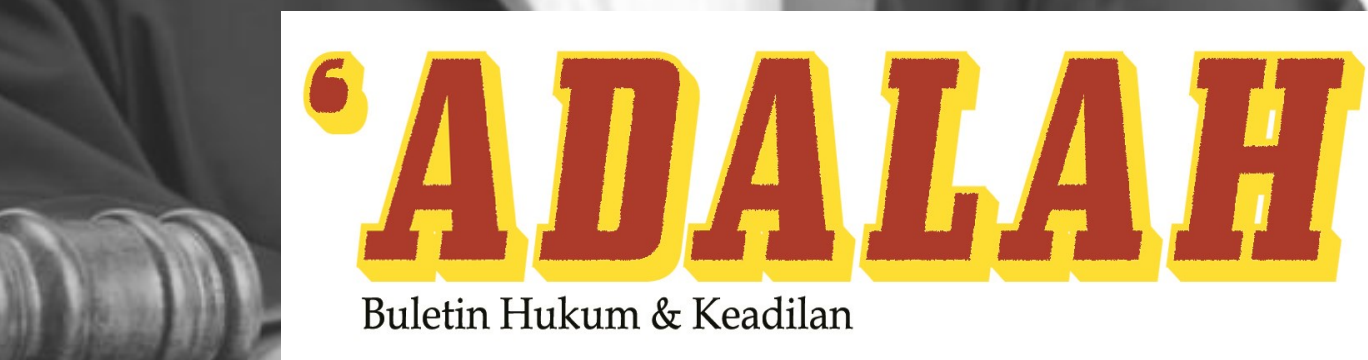

Buletin Hukum \& Keadilan

\title{
Hukum dan Hak Asasi Manusia (HAM) Pekerja Anak Dalam Masa Pandemi Covid 19 Di Indonesia
}

\author{
Indra Rahmatullah \\ Universitas Islam Negeri Syarif Hidayatullah Jakarta \\ do \\ 10.15408/adalah.v4i1.18956
}

\begin{abstract}
:
Covid 19 hit Indonesia since early 2020 and has huge impact on the child protection in Indonesia. The economic and business activity which was hit by the pandemic has resulted in many industrial sectors being forced to conduct efficiency, reduce employees, and job terminated (PHK). Moreover, the informal sector must struggle to survive in uncertain condition. This situation affects the economic family, especially middle to lower level, which is crushed by economic problem so that children are forced to become workers to help their family's economy. Therefore, protection of human rights law for children is needed.
\end{abstract}

Keywords: Covid-19, Child and Human Rights

\section{Abstrak:}

Covid 19 yang melanda Indonesia sejak awal tahun 2020 membawa dampak sangat besar terhadap perlindungan anak di Indonesia. Geliat ekonomi dan bisnis yang terpukul dari pandemi ini mengakibatkan banyak sektor industri yang terpaksa melakukan efisiensi perusahaan, pengurangan karyawan, pemotongan gaji bahkan harus gulung tikar sehingga melakukan pemutusan hubungan kerja (PHK). Apalagi sektor informal yang harus bersusah payah bertahan dalam kondisi tak menentu. Situasi ini berpengaruh pada tingkat ekonomi keluarga khususnya level menengah ke bawah yang terhimpit masalah ekonomi sehingga anak terpaksa menjadi pekerja demi membantu ekonomi keluarganya. Oleh karena itu dibutuhkan perlindungan hukum HAM bagi anak.

Kata Kunci: Covid-19, Anak dan Hak Asasi Manusia 


\section{Prolog}

Pandemi Covid-19 yang melanda hampir seluruh negara di dunia pada akhir tahun 2019 sampai dengan sekarang telah membawa perubahan kehidupan sosial yang sangat besar. Imbasnya bukan hanya pada sektor kesehatan, di mana setiap negara berupaya untuk meminimalisir penyebaran infeksi virus corona dan berburu vaksinnya, tetapi juga terdapat efek domino yaitu berbagai sektor yang secara tidak langsung ikut merasakannya. Dari sektor kesehatan, sampai dengan 30 Oktober 2020 terdapat 219 Negara yang mengalami masalah ini, terkonfirmasi positif sebanyak 44.592.789 jiwa dan 1.175.553 meninggal dunia. Sedangkan di Indo-

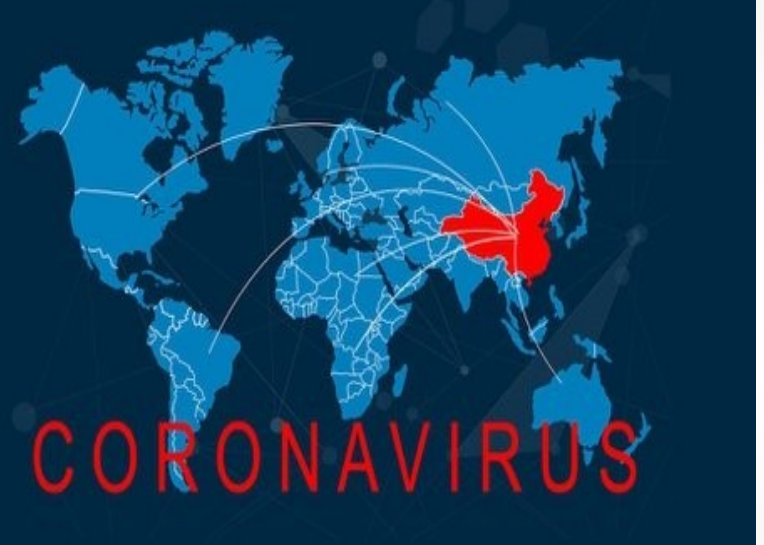

nesia, pertanggal 30 Oktober 2020 menurut Komite Penganganan Covid-19 dan PEN, pasien positif 406.945 orang, pasien sembuh 334.295 orang dan meninggal dunia 13.782 orang.

Sedangkan kehidupan sosial terdapat perlambatan perekonomian karena operasionalisasi sektor bisnis tidak berjalan normal bahkan harus gulung tikar karena tidak mampu lagi bertahan dari derasnya badai pandemi ini. Beberapa sektor bisnis yang paling terdampak pandemi di mana 3 sektor yang paling tinggi terdampak yaitu: akomodasi makanan dan minuman 92,47\%, transportasi dan pergudangan 90,34\%, dan jasa lainnya 90,90\%. Sedangkan 3 sektor yang terendah yaitu: sektor air dan pengolahan sampah 68\%, listrik dan gas 67,85\%, real estate 59,15\% (BPS, 2020).

Terganggunya operasional sektor industri memgakibatkan banyak perusahaan yang melakukan efisiensi tenaga kerjanya karena sudah tidak mampu membayar gaji. Jalan yang ditempuh dengan melakukan Pemutusan Hubungan Kerja (PHK) kepada karyawan 
sehingga potensi kemiskinan semakin melebar. Banyak kepala keluarga sudah tidak mampu lagi menafkahi istri dan anaknya. Ironisnya, kondisi sulit ini menggiring anak terpaksa ikut membantu perekonomian keluarga.

Bahkan menurut ILO, selama pandemi ini ada sekitar 42-66 juta anak berpotensi menjadi pekerja demi membantu perekonomian keluarga dan secara umum sekitar 386 juta anak ikut bekerja sampai dengan tahun 2019 (ILO, 2020: 15). Sedangkan di Indonesia, Filantropi Tanggap Covid-19 mencatat ada sekitar 11 juta anak yang berpotensi menjadi pekerja jika selama pandemi ini belum usa.

Memang ada keterkaitan antara pandemi dengan anak yang menjadi pekerja. Penyebabnya 2 hal, yaitu: Pertama, orang tua yang kesulitan ekonomi dengan terpaksa menjadikan anak melakukan tugas perbantuan dengan bekerja demi menolong ekonomi keluarganya (HRW, 2020). Kedua, disrupsi sektor pendidikan. Imbas sekolah tidak melakukan kegiatan belajar mengajar, banyak anak terpaksa tidak terkontrol belajarnya bahkan sampai dengan tidak melanjutkan sekolah dan kemudian menjadikan mereka sebagai pekerja (ASI, 2020).

Jika sekolah-sekolah tutup dan anak harus keluar dari sekolah serta ditambah dengan masalah ekonomi di keluarga maka akan menimbulkan masalah anak baru yaitu maraknya perkawinan anak dan pekerja anak. Bahkan jika pandemi ini berlangsung selama 2 tahun, diprediksi akan ada 4 juta anak perempuan yang berpotensi kawin di bawah umur dan menjadi pekerja anak (Batha E, 2020).

\section{Kewajiban Negara Melindungi Pekerja Anak Dalam Hukum Inter- nasional dan Nasional}

Pengaturan anak yang bekerja atau pekerja anak mendapat perhatian yang serius dari berbagai negara. Hal ini merupakan bentuk upaya dari negara-negara di dunia untuk memberikan perlindungan khusus dan pemenuhan terhadap hak-hak anak yang tidak 
dapat ditawar-tawar. Jenis aturan hukum tersebut dapat berskala internasional maupun nasional.

Membahas tentang anak tidak dapat dilepaskan dari diskusi tentang Hak Asasi Manusia karena perlindungan anak ada dalam konsep HAM. Hak asasi manusia adalah hak-hak yang dimiliki manusia semata-mata karena ia manusia. HAM melekat pada manusia karena tidak diberikan kepadanya oleh masyarakat atau berdasarkan hukum positif, melainkan semata-mata berdasarkan martabatnya sebagai manusia. Setiap orang terlahir dengan warna kulit, jenis kelamin, bahasa, budaya dan kewarganegaraan yang berbedabeda, ia tetap mempunyai hak-hak tersebut. Inilah sifat universal dari HAM dan tidak dapat dicabut oleh alasan apapun (Rhona Smith, 2008: 11).

Untuk memberikan pedoman tertulis bagi semua negara, terdapat Universal Declaration of Human Rights (UDHR) atau Deklarasi Umum Hak Asasi Manusia (DUHAM). DUHAM adalah dokumen yang monumental bagi sejarah manusia dalam konteks penghormatan terhadap HAM. DUHAM didraft oleh perwakilan-perwakilan dari berbagai latar belakang budaya seluruh negara di dunia dalam komitmennya meneguhkan prinsip-prinsip HAM dan dideklarasikan pada tanggal 10 Desember 1948 sebagai sebuah pedoman umum bagi semua orang dan semua negara di dunia yang berisikan tentang hak dasar sebagai manusia yang secara universal dilindungi dan melekat pada setiap diri manusia. Bahkan, dokumen DUHAM ini sudah diterjemahkan lebih dari 500 bahasa di dunia.

Terkait dengan anak sebagai bagian dari Hak Asasi Manusia, DUHAM menyatakan bahwa semestinya tidak ada kewajiban bagi anak untuk bekerja. Anak justru harus mendapatkan perhatian dan bantuan khusus dari negara melalui semua upaya perlindungan. Hal ini dinyatakan dalam Pasal 25 ayat 2 DUHAM bahwa: "Ibu dan anakanak berhak mendapatkan perhatian dan bantuan khusus. Semua anak, baik yang dilahirkan di dalam maupun di luar perkawinan, harus menikmati perlindungan sosial yang sama". 
Selain itu, terdapat International Covenant on Civil and Political Rights (ICCPR) yang merinci hak-hak sipil, politik dan melekat pada diri setiap orang sebagaimana yang diatur dalam DUHAM. Indonesia telah meratifikasi ICCPR pada 28 Oktober 2005 melalui Undang-Undang Republik Indonesia Nomor 12 Tahun 2005 Tentang Pengesahan International Covenant on Civil and Political Rights (Kovenan Internasional Tentang Hak-Hak Sipil dan Politik).

Khusus tentang anak, ICCPR mengaturnya dalam Pasal 24 ayat 1: "Setiap anak, tanpa diskriminasi yang berkenaan dengan ras, warna kulit, jenis kelamin, bahasa, agama, asal-usul kebangsaan atau sosial, harta benda atau kelahiran, berhak atas upaya-upaya perlindungan sebagaimana yang dibutuhkan oleh statusnya sebagai anak di bawah umur, oleh keluarga, masyarakat dan Negara."

Perhatian serius dari negara-negara dunia sebagai upaya melindungi hak anak terus berlanjut. Hal ini ditandai dengan adanya kesepakatan perlunya keseragaman dari berbagai negara menangani perlindungan hak-hak anak dari eksploitasi ekonomi melalui Convention on the Rights of the Child. Indonesia menandatangani konvensi tersebut pada tanggal 26 Januari dan meratifikasi pada tanggal 5 September tahun 1990 melalui Keputusan Presiden Nomor 36 Tahun 1990.

Dalam Pasal 32 Convention on the Rights of the Child tersebut mengamanahkan kepada negara-negara untuk mengakui hak anak untuk dilindungi dari eksploitasi ekonomi (Kanyaka Prajnaparamita, 2018: 118) dan dari pelaksanaan setiap pekerjaan yang mungkin berbahaya atau mengganggu pendidikannya, atau merugikan kesehatan anak atau perkembangan fisik, mental, spiritual, moral atau sosial anak. Konvensi ini sangat menekankan kepada anak supaya mendapat perlindungan dari praktik-praktik eksploitasi ekonomi, seperti bekerja layaknya seperti orang dewasa. Oleh karena itu, anak memiliki hak-hak yang wajib diipenuhi oleh orang tua, masyarakat dan negara.

Pasal 32 Convention on the Rights of the Child, kemudian 
memberikan kewenangan kepada negara-negara untuk melakukan tindakan-tindakan preventif agar anak tidak terjerembab dalam praktik eksploitasi ekonomi dengan cara negara-negara berkewajiban untuk menetapkan batasan umur atau usia yang dapat bekerja, kriteria pekerjaan, dan penegakan hukumnya.

Menindaklanjuti ketentuan Pasal 32 konvensi anak di atas, International Labour Organization/ILO sebagai sebuah badan PBB yang khusus menangani permasalahan tenaga kerja dunia terpanggil untuk melakukan penetapan batasan umur anak sehingga jelas kriteria seseorang yang dapat bekerja. Pada tahun 1973, ILO menetapkan konvensi internasional yang mengatur batasan umur anak melalui ILO Convention No. 138 concerning Minimum Age for Admission to Employment.

Tujuan dari Konvensi ILO ini untuk menghilangkan pekerja anak yang dapat membahayakan kesehatan, keamanan, moral dan haknya untuk mendapatkan pendidikan. Dalam konvensi ini, ILO menetapkan beberapa ketentuan sebagai berikut:

1. Negara anggota ILO yang mengesahkan Konvensi ini wajib menetapkan kebijakan nasional untuk menghapuskan praktik mempekerjakan anak dan meningkatkan usia minimum untuk diperbolehkan bekerja.

2. Untuk pekerjaan-pekerjaan yang membahayakan kesehatan, keselamatan, atau moral anak harus diupayakan tidak boleh kurang dari 18 (delapan belas) tahun, kecuali untuk pekerjaan ringan tidak boleh kurang dari 16 (enam belas) tahun.

3. Negara anggota ILO yang mengesahkan Konvensi ini wajib menetapkan usia minimum untuk diperbolehkan bekerja, aturan mengenai jam kerja, dan menetapkan hukuman atau sanksi yang menjamin pelaksanaannya.

4. Negara anggota ILO yang mengesahkan Konvensi ini wajib melaporkan pelaksanaannya. 
Ketentuan-ketentuan dalam konvensi tersebut sudah diratifikasi oleh Indonesia melalui Undang-Undang Nomor 20 Tahun 1999 tentang Pengesahan ILO Convention No. 138 Concerning Minimum Age for Admission to Employment (Konvensi ILO mengenai Usia Minimum untuk Diperbolehkan Bekerja).

Konvensi ILO No. 138 telah memberikan rambu kuning batasan diperbolehkannya seseorang yang dapat bekerja. Namun demikian, konvensi tersebut belum mempertegas pekerjaan apa saja yang berbahaya bagi anak sehingga anak secara hukum dibawah usia 16 tahun tidak diperbolehkan untuk bekerja. Oleh karena itu, untuk melengkapi dan merespon dari Konvensi ILO No. 138, ILO menetapkan Kembali konvensi internasional untuk mempertegas pekerjaan-pekerjaan yang berbahaya bagi anak melalui ILO Convention No. 182 Concerning The Prohibition and Immidiate Action for The Elimination of The Worst Forms of Child Labour (Konvensi ILO No. 182 mengenai Pelarangan dan Tindakan Segera Penghapusan BentukBentuk Pekerjaan Terburuk untuk Anak).

Konvensi ini dibuat pada tahun 1999 di Jenewa dengan tujuan pelarangan bagi anak di bawah 18 tahun untuk terlibat dalam angkatan perang, prostitusi, pornografi, perdagangan obat, dan pekerjaan-pekerjaan bahaya lainnya. Saat ini, sudah ada 147 negara yang sudah meratifikasi konvensi ini termasuk Indonesia melalui Undang-Undang Nomor 1 Tahun 2000.

Konvensi ini mengatur hal-hal sebagai berikut:

1. Negara anggota ILO yang mengesahkan Konvensi ini wajib mengambil tindakan segera dan efektif untuk menjamin pelarangan dan penghapusan bentuk-bentuk pekerjaan terburuk untuk anak.

2. "Anak" adalah semua orang yang berusia di bawah 18 (delapan belas) tahun.

3. Pengertian dari "bentuk-bentuk pekerjaan terburuk untuk anak" adalah: 
(a) segala bentuk perbudakan seperti penjualan dan perdagangan anak, kerja ijon (debt bondage), dan perhambaan serta kerja paksa atau wajib kerja, termasuk pengerahan anak secara paksa atau wajib untuk dimanfaatkan dalam konflik bersenjata;

(b). pelacuran, untuk produksi pornografi, atau untuk pertunjukan-pertunjukan porno;

(c). produksi dan perdagangan obat-obatan sebagaimana diatur dalam perjanjian internasional yang relevan;

(d). pekerjaan yang sifat atau keadaan tempat pekerjaan itu dilakukan dapat membahayakan kesehatan, keselamatan, atau moral anak-anak.

Di Indonesia, hukum nasional yang mengatur perlindungan anak dari eksploitasi ekonomi sudah lengkap dan telah sesuai dengan ketentuan-ketentuan hukum internasional. Hal ini bisa dimulai dari Undang-Undang Nomor 39 Tahun 1999 Tentang Hak Asasi Manusia Pasal 64 bahwa "Setiap anak berhak untuk memperoleh perlindungan dari kegiatan eksploitasi ekonomi dan setiap pekerjaan yang membahayakan dirinya, sehingga dapat mengganggu pendidikan, kesehatan fisik, moral, kehidupan sosial, dan mental spiritualnya."

Undang-Undang No. 39 Tahun 1999 tentang HAM, sangat jelas melarang praktik-praktik eksploitasi yang memanfaatkan anak sebagai pekerja. Hal ini bertujuan semata-mata untuk memberikan hak anak agar dapat tumbuh kembang secara normal sesuai dengan fitrahnya yang digariskan oleh Tuhan Yang Maha Esa.

Selain itu, ada Undang-Undang No. 23 Tahun 2002 tentang Perlindungan Anak yang spesifik memberikan perlindungan hukum kepada anak. Latar belakang hadirnya undang-undang ini karena dirasakan belum cukup memadai melalui Undang-undang Nomor 39 Tahun 1999 tentang Hak Asasi Manusia yang mencantumkan tentang hak anak, pelaksanaan kewajiban dan tanggung jawab orang 
tua, keluarga, masyarakat, pemerintah, dan negara untuk memberikan perlindungan. Oleh karena itu masih diperlukan suatu undang-undang khusus mengenai perlindungan anak sebagai landasan yuridis bagi pelaksanaan kewajiban dan tanggung jawab tersebut. Pasal 4 menyatakan bahwa "Setiap anak berhak untuk dapat hidup, tumbuh, berkembang, dan berpartisipasi secara wajar sesuai dengan harkat dan martabat kemanusiaan, serta mendapat perlindungan dari kekerasan dan diskriminasi."

Terkait dengan pekerja anak, Undang-Undang Ketenagakerjaan sangat jelas melarang memperkerjakan anak dalam Pasal 68 Undang-Undang No. 13 Tahun 2003 Tentang Ketenagakerjaan bahwa "Pengusaha dilarang memperkerjakan anak. Bagi pengusaha yang memperkerjakan anak di bawah umur, akan dikenakan sanksi pidana berupa pidana penjara paling singkat 1 (satu) tahun dan paling lama 4 (empat) tahun dan/atau denda paling sedikit Rp 100.000.000,00 (seratus juta rupiah) dan paling banyak $\mathrm{Rp}$ 400.000.000,00 (empat ratus juta rupiah).

Namun, apabila terpaksa ada anak yang ingin tetap berkerja, Undang-Undang telah membatasi dengan ketat bagi anak yang berumur antara 13 (tiga belas) sampai dengan 15 (lima belas) tahun untuk melakukan pekerjaan ringan sepanjang tidak mengganggu perkembangan dan kesehatan fisik, mental, dan sosial.

\section{Epilog}

Masa Pandemi Covid-19 memiliki keterkaitan dengan rawannya anak menjadi pekerja. Pilihan sulit ini terpaksa dilakukan karena pandemi telah merampas kesejahteraan keluarganya sehingga jatuh pada garis kemiskinan baru. Problemnya bukan hanya pada sisi ekonomi tetapi juga menjadi pemicu masalah sosial lainnya seperti maraknya perkawinan anak dan eksploitasi seksual.

Negara berkewajiban meminimalisir dan menghilangkan fenomena ini demi keberlangsungan hak-hak anak agar terpenuhi 
dengan maksimal. Negara dalam setiap kebijakan yang diambil harus mempertimbangkan kepentingan terbaik anak, sehingga realisasinya baik dalam anggaran maupun program kepentingan anak harus menjadi prioritas dibandingkan dengan sektor lainnya sebagaimana amanah dalam Undang-Undang Hak Asasi Manusia.

\section{DAFTAR PUSTAKA}

ASI (2020). Leaving No-one Behind: Guidance for policymakers, donors and business leaders to ensure that responses to Covid-19 reach victims of modern slavery and people vulnerable to slavery. Anti-Slavery International (ASI). https:// www.antislavery.org/wp-content/uploads/2020/04/ASI_Leaving -noone-behind-April-2020-1.pdf

Batha, E. (2020). 'Coronavirus puts 4 million girls at risk of child marriage'. Thomas Reuters Foundation, 14 May 2020. https:// news.trust.org/item/20200514221931-3k1vf/?

utm_campaign=trending\&utm_medium=trendingWebWidget\& utm_source=detailPage\&utm_content=link4.

Cranston, Maurice. What are Human Rights? Taplinger, New York, 1973.

Donnely, Jack. Universal Human Rights in Theory and Practice, Cornell University Press, Ithaca and London, 2003.

HRW (2020). COVID-19 and children's rights. Human Rights Watch, 9 April 2020. https://www.hrw.org/news/2020/04/09/covid-19and-childrens-rights-0\#_Toc37256531

https://covid19filantropi.id/cegah-eksplotasi-pekerja-anak-selamapandemi-covid-19/

International Labour Organization (ILO), Issue paper on COVID-19 and fundamental principles and rights at work, 2020. 
Prajnaparamita, Kanyaka. Perlindungan Tenaga Kerja Anak, Adminitrative Law \& Governance Journal Vol. 1 Edisi Khusus 12018.

Smith et, all, Rhona KM. Hukum Hak Asasi Manusia, Yogyakarta: Pusham UII, 2008.

\section{Dokumen Perundang-undangan}

Convention on the Rights of the Child.

International Covenant on Civil And Political Rights.

Komite Penanganan Covid-19 dan Pemulihan Ekonomi Nasional, covid19.go.id.

ILO Convention No. 138 concerning Minimum Age for Admission to Employment.

ILO convention No. 182 Concerning The Prohibition and Immidiate Action for The Elimination of The Worst Forms of Child Labour.

Universal Declaration of Human Rights.

'Adalah; Buletin Hukum dan Keadilan merupakan berkala ilmiah yang diterbitkan oleh Pusat Studi Konstitusi dan Legislasi Nasional (POSKO-LEGNAS), Fakultas Syariah dan Hukum UIN Syarif Hidayatullah Jakarta.

Penasehat: Prof. Dr. H. Abdul Ghani Abdullah, SH., Prof. Dr. H. A Salman Maggalatung, SH., MH. Tim Redaktur: Indra Rahmatullah, Mara Sutan Rambe, Muhammad Ishar Helmi, Erwin Hikmatiar, Fathuddin, Nurrohimyunus. Penyunting: Latipah Nasution, Siti Nurhalimah, Siti Romlah. Setting \& Layout: Imas Novita Juaningsih, Rezky Panji Perdana Martua Hasibuan, Azizah Ratu Buana. 